\title{
GeoSites i Danmark \\ - deltag i projektet
}

\section{Af Erik Nygaard, GEUS}

GeoSites er en beskrivelse af danske geologiske og geomorfologiske lokaliteter af international videnskabelig værdi, som alle kan bidrage til.

Der er mange lokaliteter i Danmark, som viser dele af historien om landskabets dannelse. Ca. 200 sådanne illustrative lokaliteter er udpeget som nationale geologiske interesseområder, som bør nyde en form for beskyttelse. De er beskrevet i bogserien Geologisk Set, som udgives af Skov- og Naturstyrelsen og Geografforlaget. En del af disse lokaliteter er så videnskabeligt betydningsfulde, at de bør indgå i den internationale liste over GeoSites.

\section{Hjemmesiden www.geosites.dk}

På hjemmesiden www.geosites.dk kan du finde beskrivelser af de ca. 40 lokaliteter, som pt. er foreslået som GeoSites. Beskrivelserne foreligger nu som tekstudkast. Nogle beskrivelser er næsten færdige, mens der $\mathrm{i}$ den anden ende er nogle, der kun består af overskrifter.

\section{Tilføjelser er velkomne}

Hjemmesiden er etableret for løbende at kunne vise en opdateret status for beskrivelserne, så alle geo-folk har mulighed for at komme med supplerende bidrag/kommentarer. Derfor er der en kommenteringsmulighed i forbindelse med alle beskrivelserne. Kommentarerne gemmes, og redaktionen på GEUS sammensætter et udkast til endelig beskrivelse. Vi er fx interesserede i nyere internationale refe-

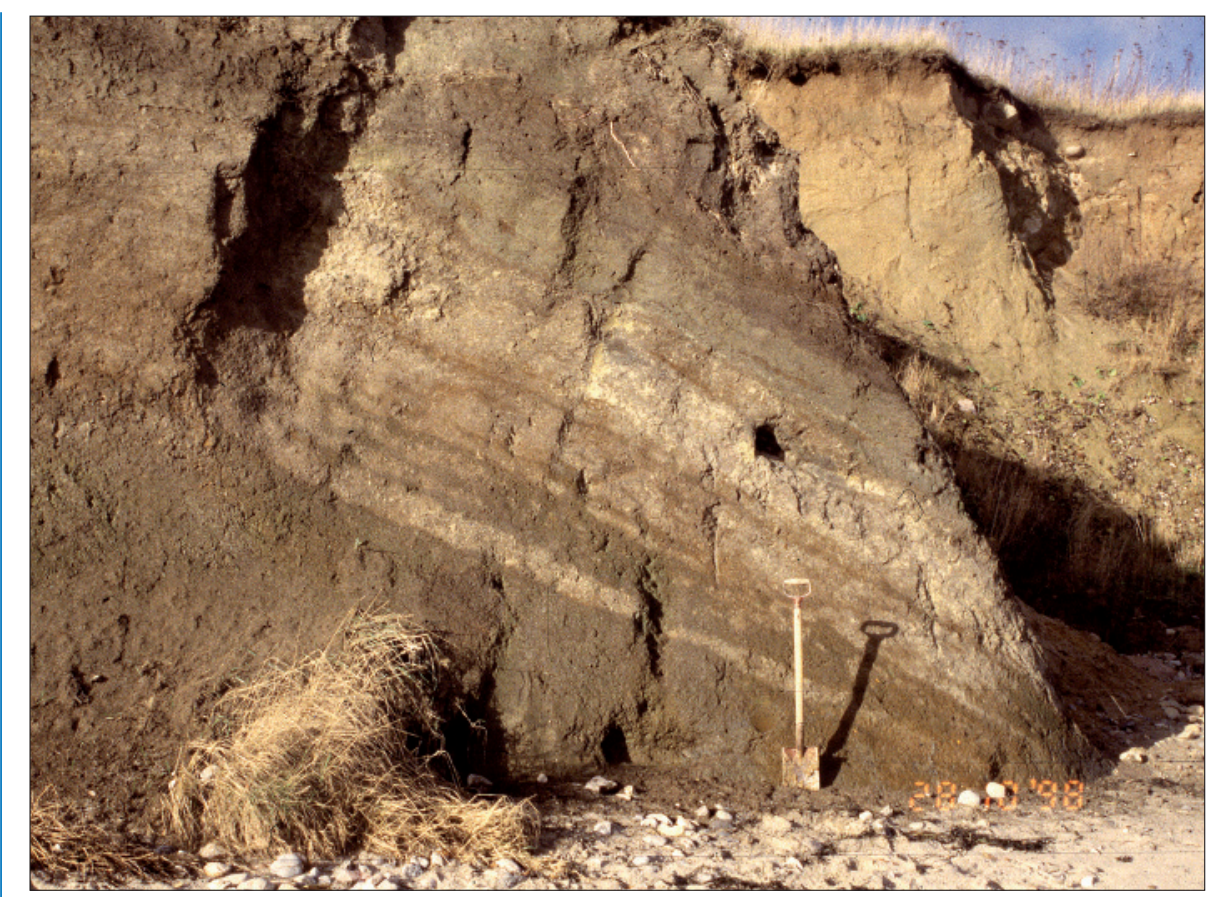

Klintprofil ved Mommark med Cyprina Ler fra Eem. (Foto: Svend Funder (1998) fra Geologisk Set, Det Sydlige Jylland)

rencer, der viser, at den pågældende lokalitet har international interesse.

Der kan løbende tilføjes nye lokaliteter, som er opstået eller har været overset. Læs mere om formål, organisering og processen på hjemmesiden. Beskrivelserne færdiggøres som oplæg i foråret 2006 og diskuteres på et afslutingsmøde 8/6 kl. 16-17:30, på Geologisk Museum, Auditorium A. GeoSites vil herefter være hovedtema for Geologiens Dage, 30/9-1/10.

\section{Info}

Klik ind på www.geosites.dk GeoSites-lokaliteterne.

Materialet samles af:

GEUS v. Merete Binderup (mb@geus.dk) og Erik Nygaard (eny@geus.dk). og giv dit faglige bidrag til 